\title{
ANALISIS EFISIENSI BIAYA TERHADAP KEPUTUSAN PENGGUNAAN OUTSOURCING BIDANG CLEANING SERVICE DAN CATERING PADA PT KUWERA JAYA JAKARTA
}

\author{
Masruroh; Ferry Fernanda; Tony Wibowo \\ ${ }^{1}$ Management Department, School of Business Management, Binus University \\ Jln. K.H. Syahdan No. 9, Palmerah, Jakarta Barat 11480 \\ Masruroh2000@yahoo.com
}

\begin{abstract}
Bustle to serve customers make the company should focus more on its core business. Nowadays, PT Kuwera Jaya manages and employs its own cleaning service activities and also gives money for meal to employees in supporting activities. Conditions of supporting activities make PT Kuwera Jaya analyze the cost efficiency of supporting activities either self hiring or outsourcing. This study compared the use of relevant cost for self hiring and outsourcing, so that it could be analyzed which is more efficient alternative based on the most relevant low costs. Because the plan would still be done in the future, then to consider possible changes in the future, it was created three scenarios: pessimistic, moderate, optimistics with each of the relevant assumptions for each scenario. Results of the study indicate that the three scenarios using outsourcing as a viable alternative chosen by PT Kuwera Jaya because it could minimize the cost of supporting good cleaning service activities to manage the activities of cleanliness and also catering to provide lunch for employees. Suggestion in this research is PT Kuwera Jaya should immediately decide to use outsourcing in supporting the activities of cleaning service and catering. In addition to the benefits of outsourcing for cost efficiency, the field of activity is allowed in Employment Act No 13 2003, Articles 64 to 66.
\end{abstract}

Keywords: cost efficiency, outsourcing, cleaning service, catering

\begin{abstract}
ABSTRAK
Kesibukan dalam melayani pelanggan membuat perusahaan harus lebih fokus pada core business. Selama ini PT Kuwera Jaya mengelola dan mempekerjakan sendiri aktivitas cleaning service dan juga memberikan uang makan bagi karyawan kegiatan penunjang. Kondisi kegiatan penunjang ini dapat membuat PT Kuwera Jaya mengefisiensikan segala biaya yang ada. Salah satunya, menganalisis efisiensi biaya kegiatan penunjang, yaitu dengan mempekerjakan sendiri seperti yang selama ini dilakukan atau dengan alternatif menggunakan outsourcing bagi kegiatan penunjang. Penelitian ini mengunakan relevan cost atas biaya memperkerjakan sendiri dan alternatif pengunaan outsourcing, sehingga dapat dianalisis alternatif mana yang lebih efisien berdasarkan pada biaya relevan atas biaya setiap alternatif yang paling rendah. Karena rencana ini masih akan dilakukan pada masa yang akan datang maka untuk mempertimbangkan kemungkinan perubahan pada masa yang akan datang, dibuat tiga skenario yaitu pesimis, moderat, optimis dengan masing-masing asumsi yang relevan untuk setiap skenario. Hasil penelitian ketiga skenario tersebut menunjukkan bahwa alternatif menggunakan outsourcing yang layak dipilih oleh PT Kuwera Jaya Jakarta karena dapat mengefisienkan biaya kegiatan penunjang baik cleaning service untuk mengelola aktivitas kebersihan dan juga catering untuk menyediakan makan siang bagi karyawan. Saran yang dapat diajukan dalam penelitian ini adalah sebaiknya PT Kuwera Jaya segera memutuskan untuk menggunakan outsourcing atas kegiatan penunjang yakni cleaning service dan catering. Selain manfaat adanya efisiensi biaya, outsourcing di bidang kegiatan ini diperbolehkan dalam Undang-Undang Ketenagakerjaan No.13 Tahun 2003 Pasal 64 - 66.
\end{abstract}

Kata kunci: efisiensi biaya, outsourcing, cleaning service, catering 


\section{PENDAHULUAN}

Persaingan dalam dunia bisnis antarperusahaan membuat perusahaan harus berkonsentrasi pada rangkaian proses atau aktivitas penciptaan produk dan jasa yang terkait dengan core business. Konsentrasi terhadap core business perusahaan akan menghasilkan sejumlah produk dan jasa yang berkualitas dengan daya saing di pasaran. Dalam iklim persaingan usaha yang makin ketat perusahaan berusaha untuk melakukan efisiensi biaya produksi (cost of production) (Wirawan, n.d.). Salah satu solusinya adalah dengan sistem outsourcing. Dengan sistem ini perusahaan dapat menghemat pengeluaran dalam membiayai sumber daya manusia (SDM) yang bekerja di perusahaan yang bersangkutan. (Wirawan, n.d.)

Menurut David (2011), perusahaan memilih menggunakan outsourcing di dalam fungsi operasional karena beberapa alasan. Di antaranya adalah biaya yang dikeluarkan lebih sedikit, membuat perusahaan lebih fokus pada core business, dan juga perusahaan dapat memberikan layanan yang lebih baik. Outsourcing diartikan sebagai pemindahan atau pendelegasian beberapa proses bisnis kepada suatu badan penyedia jasa, sehingga badan penyedia jasa tersebut melakukan proses administrasi dan manajemen berdasarkan definisi serta kriteria yang telah disepakati oleh para pihak. Outsourcing dalam hukum ketenagakerjaan di Indonesia diartikan sebagai pemborongan pekerjaan dan penyediaan jasa tenaga kerja. Pengaturan hukum outsourcing di Indonesia diatur dalam UndangUndang Ketenagakerjaan Nomor 13 tahun 2003 (pasal 64, 65, dan 66) dan Keputusan Menteri Tenaga Kerja dan Transmigrasi Republik Indonesia No.Kep.101/Men/VI/2004 Tahun 2004 tentang Tata Cara Perijinan Perusahaan Penyedia Jasa Pekerja/Buruh (Kepmen 101/2004).

Outsourcing tidak dapat dipandang secara jangka pendek saja karena dengan menggunakan outsourcing perusahaan pasti akan mengeluarkan dana lebih sebagai management fee perusahaan outsourcing. Outsourcing harus dipandang secara jangka panjang, mulai dari pengembangan karier karyawan, efisiensi dalam bidang tenaga kerja, organisasi, keuntungan, dan lainnya. Dengan menggunakan outsourcing, maka perusahaan dapat fokus pada kompetensi utama dalam bisnis sehingga dapat berkompetisi dalam pasar. Hal-hal internal perusahaan yang bersifat penunjang (supporting) dialihkan kepada pihak lain yang lebih profesional (perusahaan outsourcing).

PT Kuwera Jaya merupakan perusahaan yang bergerak dalam bidang jasa ticketing. Melihat penggunaan outsourcing yang dapat meningkatkan efisiensi biaya bagi perusahaan, tentunya hal ini menjadi pertimbangan tersendiri. Oleh karena itu sebagai perusahaan yang bergerak dalam bidang jasa, PT Kuwera Jaya perlu lebih fokus terhadap core business. Sedangkan kegiatan penunjang pada perusahaan seperti cleaning service dan penyediaan catering dapat diserahkan pada perusahaan outsourcing.

Sementara itu, penggunaan outsourcing masih sangat menguntungkan perusahaan, di luar isuisu yang beredar mengenai ketenagakerjaan beberapa tahun terakhir. Misalkan masalah benefit, tentunya ada perbedaan antara karyawan outsourcing dengan karyawan pada perusahaan pengguna outsourcing. Hal-hal yang terdapat pada peraturan perusahaan yang disepakati untuk ditaati akan disosialisasikan kepada karyawan outsourcing oleh perusahaan outsourcing. Sosialisasi ini penting untuk meminimalkan tuntutan dari karyawan outsourcing yang menuntut dijadikan karyawan tetap pada perusahaan pengguna jasa outsourcing karena kurangnya informasi tentang hubungan hukum antara karyawan dengan perusahaan pengguna outsourcing. Dalam hal ini, perusahaan outsourcing harus bisa menempatkan diri dan bersikap bijaksana agar bisa mengakomodasi kepentingan karyawan maupun perusahaan pengguna jasa pekerja, mengingat perusahaan pengguna jasa pekerja sebenarnya adalah pihak yang lebih mengetahui keseharian performa karyawan daripada perusahaan outsourcing itu sendiri. 
Melihat isu-isu yang berkembang tersebut, muncullah permasalahan bagi PT Kuwera Jaya untuk memilih menggunakan outsourcing atau mempekerjakan sendiri karyawan dalam kegiatan penunjang, yaitu cleaning service dan penyediaan catering. Oleh sebab itu, penelitian dilakukan untuk meneliti keputusan perusahaan menggunakan outsourcing yang berpengaruh terhadap efisiensi biaya di PT Kuwera Jaya.

Rumusan masalah dalam penelitian adalah sebagai berikut. Pertama, bagaimana perbandingan biaya keputusan outsourcing dengan keputusan mempekerjakan sendiri pada kegiatan bidang cleaning service dan catering pada PT Kuwera Jaya. Kedua, seberapa besar penghematan biaya atas keputusan outsourcing yang dilakukan oleh PT Kuwera Jaya. Dengan demikian, tujuan penelitian ini adalah sebagai berikut. Pertama, untuk mengetahui perbandingan biaya keputusan outsourcing dengan keputusan mempekerjakan sendiri pada kegiatan bidang cleaning service dan catering pada PT Kuwera Jaya. Kedua, untuk mengetahui besar penghematan biaya atas keputusan outsourcing yang dilakukan PT Kuwera Jaya.

\section{Kerangka Teoretis dan Kerangka Penelitian}

\section{Bisnis}

Hughes dan Kapoor (Sugiono, 2004) menyatakan: "Business is the organized of individuals to produce and self a profit, the good and service that satisfy society's needs. The general term business refers to all such effort within a society or within an industry." Maksudnya bisnis adalah suatu kegiatan individu atau organisasi yang secara hukum terorganisasi untuk menjual dan menghasilkan barang dan jasa guna mendapat keuntungan dalam memenuhi kebutuhan masyarakat. Alma (2003) menyatakan bahwa bisnis adalah sejumlah total usaha yang meliputi bidang pertanian, produksi, konstruksi, distribusi, transportasi, komunikasi, perhotelan, usaha jasa, dan pemerintahan yang bergerak dalam bidang membuat dan memasarkan barang dan jasa ke konsumen.

\section{Perencanaan Bisnis}

Menurut Madura (2007) rencana bisnis adalah suatu deskripsi rinci dari suatu usulan bisnis, termasuk di dalamnya deskripsi bisnis, jenis pelanggan yang ingin ditarik, persaingan, dan fasilitas yang diperlukan untuk produksi. Sedangkan menurut Suryana (2008) perencanaan usaha adalah suatu cetak biru tertulis yang berisikan misi usaha, usulan usaha, operasional usaha, rincian strategis, dan peluang yang mungkin diraih.

\section{Biaya}

Biaya merupakan aspek yang mutlak di perusahaan mana pun. Besar kecilnya biaya yang dikeluarkan perusahaan tergantung dari tingkat kebutuhan yang diperlukan untuk mencapai tujuan. Menurut Horngren, Datar, dan Foster (2008): "Biaya adalah suatu sumber daya yang dikorbankan (sacrificed) atau dilepaskan (forgone) untuk mencapai tujuan tertentu." "Biaya adalah arus keluar atau pengkonsumsian aset dan atau timbulnya kewajiban selama suatu periode yang berasal dari pengiriman dan produksi barang, penyerahan jasa, atau penyelenggara aktivitas-aktivitas lainnya yang merupakan operasi utama dari suatu entitas.”

\section{Klasifikasi Biaya}

Menurut Usry, Carter, dan Thomson (2004), "keberhasilan dalam merencanakan dan mengendalikan biaya tergantung pada pemahaman yang menyeluruh atas hubungan antara biaya dan aktivitas bisnis. Studi dan analisis yang hati-hati atas dampak aktivitas bisnis atas biaya umumnya 
akan menghasilkan klasifikasi tiap pengeluaran sebagai biaya tetap, biaya variabel, atau biaya semivariabel." Pertama, biaya tetap didefinisikan sebagai biaya yang secara total tetap tanpa berhubungan dengan peningkatan aktivitas. Kedua, biaya variabel didefinisikan sebagai biaya yang secara total meningkat secara proposional terhadap peningkatan dalam akitivtas. Ketiga, biaya semivariabel didefinisikan sebagai biaya yang memperlihatkan baik karakteristik-karakteristik dari biaya tetap maupun biaya variabel.

\section{Objek Biaya dan Pemicu Biaya}

Objek biaya dan pemicu biaya bervariasi tergantung pada bentuk dan sifat organisasi dan objek biayanya. Objek biaya merupakan aktivitas yang mengakumulasikan biaya. Lima jenis objek biaya adalah produk atau kelompok produk yang saling berhubungan, jasa, departemen, proyek (proyek penelitian, pemasaran). Jumlah total biaya untuk suatu objek biaya dipengaruhi oleh cost driver. Cost driver merupakan faktor-faktor yang mempunyai efek terhadap perubahan level biaya untuk sebuah objek biaya. Sebagai contoh, biaya listirk dalam pabrik (objek biaya) dipengaruhi oleh jumlah jam mesin. Jadi, jumlah jam mesin merupakan cost driver untuk biaya listrik. Cost driver merupakan langkah penting dalam analisis strategis dan manajemen biaya pada sebuah perusahaan. Identifikasi dan analisis cost driver tersebut merupakan dasar dalam penentuan biaya dan objek biaya secara akurat dan untuk pengendalian biaya objek tersebut.

\section{Biaya Langsung dan Biaya Tak Langsung}

Pembebanan biaya langsung dan alokasi biaya (biaya langsung dan biaya tak langsung). Pembebanan biaya merupakan proses pembebanan biaya ke dalam cost pool atau ke cost object secara mudah dan dapat dihubungkan secara ekonomi. Contohnya, biaya yang dibutuhkan untuk produk tertentu merupakan biaya langsung karena biaya tersebut dapat ditelusuri secara langsung ke produk.

Dalam perusahaan angkutan udara, biaya penyiapan, dan pemrosesan tiket penumpang merupakan biaya langsung dari jasa yang diberikan kepada pelanggan. Sebaliknya, biaya tak langsung, tidak dapat ditelusuri secara mudah sulit dihubungkan secara ekonomi dari biaya cost pool ke cost pool atau cost object.

Biaya tak langsung biasa disebabkan oleh dua atau lebih cost pool atau objek yang tidak dapat dengan mudah dan secara ekonomi ditelusuri secara langsung. Biaya pengawasan terhadap para karyawan produksi dan bagian penanganan bahan merupakan contoh yang bagus dari biaya yang pada umumnya tidak dapat ditelusuri secara langsung.

\section{Outsourcing}

Secara sederhana, outsourcing dapat diartikan sebagai praktik yang ditempuh oleh suatu perusahaan untuk menyerahkan sebagian aktivitasnya untuk dikerjakan oleh perusahaan lain sehingga organisasi perusahaan menjadi saling keterkaitan antara satu dengan yang lainya. Menurut definisi Maurice Greaver, Outsourcing dipandang sebagai tindakan mengalihkan beberapa aktivitas perusahaan dan hak pengambilan keputusannya kepada pihak lain (outside provider), yang tindakan ini terikat dalam suatu kontrak kerjasama (Faiz, 2007).

Beberapa pakar serta praktisi outsourcing dari Indonesia juga memberikan definisi mengenai outsourcing, antara lain menyebutkan bahwa outsourcing dalam bahasa Indonesia disebut sebagai alih daya, adalah pendelegasian operasi dan manajemen harian dari suatu proses bisnis kepada pihak luar (perusahaan jasa outsourcing). Pendapat serupa juga dikemukakan oleh Muzni Tambusai, Direktur Jenderal Pembinaan Hubungan Industrial Departemen Tenaga Kerja dan Transmigrasi yang mendefinisikan pengertian outsourcing sebagai memborongkan satu bagian atau beberapa bagian 
kegiatan perusahaan yang tadinya dikelola sendiri kepada perusahaan lain yang kemudian disebut sebagai penerima pekerjaan. (Faiz, 2007)

Dari definisi yang dikemukakan, terdapat persamaan dalam memandang outsourcing yaitu terdapat penyerahan sebagian kegiatan perusahaan pada pihak lain. Dalam pendekatan yang lebih strategis, outsourcing adalah merupakan kombinasi dari dua strategi. Strategi pertama, pemusatan aktivitas, investasi, alokasi sumber daya perusahaan, dan perhatian manajemen pada bidang-bidang yang memiliki tingkat kompetensi tinggi (core competence), yaitu keahlian dan keterampilan yang dimiliki perusahaan yang memungkinkanya unggul dalam mengembangkan dan memasarkan produk atau jasa yang berintikan keahlian tersebut. Kedua, pelimpahan kegiatan bidang lain yang perusahaan tidak memiliki suatu kepentingan strategis atau kemampuan khusus, sehingga perusahaan tidak perlu menjadi yang terbaik atau tidak bisa melakukan lebih baik dari perusahaan lain (Quinn \& Hilmer, 1994).

\section{Manfaat Outsourcing}

Penerapan strategi outsourcing secara tepat dapat memberikan berbagai manfaat (keuntungan) bagi perusahaan baik dari segi teknis pada masa kini maupun segi strategis pada masa yang akan datang. Pertama, meningkatkan skala efisiensi perusahaan atau mengurangi biaya (cost reduction). Kedua, memungkinkan perusahaan untuk memfokuskan perhatian pada bidang yang menjadi core competence dan value-added activities sehingga bisa mengoptimalkan return. Ketiga, mengurangi biaya investasi, outsourcing memungkinkan perusahaan kecil yang kekurangan modal tetapi mempunyai kapabilitas untuk memasuki bisnis kelas dunia. Keempat, memungkinkan perusahaan untuk memanfaatkan expert knowledge tanpa harus memiliki atau merekrut tenaga kerja dengan kemampuan tersebut. Kelima, outsourcing dapat menjadi sistem pelatihan secara tidak langsung bagi karyawan, karena hasil outsourcing dapat dipelajari oleh karyawan tentang bagaimana pekerjaan diselesaikan.

\section{Risiko Outsourcing}

Penerapan strategi outsourcing tidak berarti tanpa risiko, meskipun provider (penyedia jasa/pemasok) yang berpengalaman bersama-sama dengan perusahaan dapat mengurangi atau mengeliminasi risiko tersebut. Berbagai risiko yang paling umum terjadi, yaitu: (1) perusahaan menjadi sangat tergantung pada pemasok, hal ini akan menjadi permasalahan yang serius bila tejadi kegagalan pasar; (2) membagi informasi perusahaan kepada pemasok sehingga membuka kemungkinan pemasok untuk masuk ke dalam area bisnis perusahaan dan menjelma menjadi pesaing yang serius; (3) menyebabkan karyawan perusahaan menjadi frustasi. Karyawan perusahaan dapat memandang rencana outsoucing sebagai suatu cara untuk melempar/memecat karyawan dan memangkas biaya yang dikeluarkan oleh perusahaan.

\section{Penentuan Core Business dan Pekerjaan Penunjang dalam Perusahaan sebagai Dasar Pelaksanaan Outsourcing}

Berdasarkan Undang-Undang Ketenagakerjaan outsourcing hanya dibolehkan jika tidak menyangkut core business. Dalam penjelasan pasal 66 UU No.13 tahun 2003, disebutkan bahwa "Yang dimaksud dengan kegiatan penunjang atau kegiatan yang tidak berhubungan langsung dengan proses produksi adalah kegiatan yang berhubungan di luar usaha pokok (core business) suatu perusahaan. Kegiatan tersebut antara lain: usaha pelayanan kebersihan (cleaning service), usaha penyediaan makanan bagi pekerja/buruh catering, usaha tenaga pengaman (security/satuan pengamanan), usaha jasa penunjang pada pertambangan dan perminyakan, serta usaha penyediaan angkutan pekerja/buruh.” 
Interpretasi yang diberikan undang-undang masih sangat terbatas dibandingkan dengan kebutuhan dunia usaha saat ini. Penggunaan outsourcing makin meluas ke berbagai lini kegiatan perusahaan. Konsep dan pengertian usaha pokok atau core business dan kegiatan penunjang atau noncore business adalah konsep yang berubah dan berkembang secara dinamis.

\section{Kerangka Pemikiran}

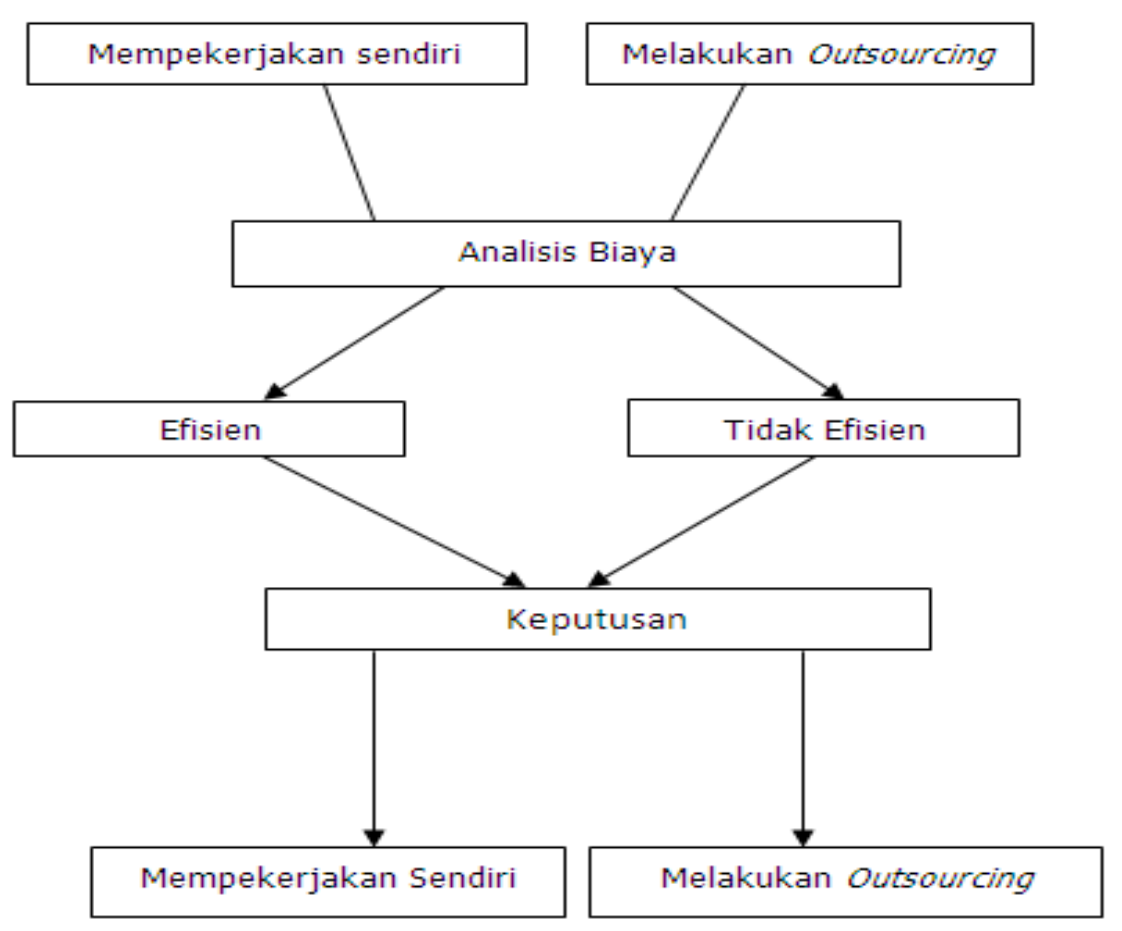

METODE

Jenis penelitian ini adalah penelitian deskriptif kualitatif dan kuantitatif. Penelitian ini berdasarkan data kuantitatif yang dianalisis secara kualitatif. Analisis terhadap keputusan perusahaan ke depannya yang mempertimbangkan untuk mempekerjakan sendiri atau menggunakan jasa dari perusahaan outsourcing. Unit penelitian adalah pada perusahaan PT Kuwera Jaya, perusahaan penyedia jasa outsourcing cleaning service, dan dari perusahaan penyedia catering yang digunakan nantinya sebagai alternatif pilihan melakukan outsourcing dalam kegiatan penunjang bagi perusahaan.

Perusahaan memiliki dua alternatif keputusan yang dapat dianalisis yaitu biaya yang dikeluarkan untuk mempekerjakan sendiri dan biaya yang dikeluarkan apabila menggunakan outsourcing dalam bidang kegiatan cleaning service dan catering. Beberapa biaya yang dikeluarkan antara lain sebagai berikut. Pertama, biaya mempekerjakan sendiri (per bulan selama 1 tahun) adalah (a) untuk cleaning service: gaji, transport, seragam kerja, peralatan kebersihan, uang makan, biaya pelatihan, biaya recruitment, asuransi; (b) untuk catering: uang makan yang diberikan karena perusahaan PT Kuwera Jaya memberikan uang kepada karyawan untuk membeli sendiri makan siang. Biaya makan per orang dikalikan frekuensi makan perhari. Kedua, biaya menggunakan outsourcing cleaning service yaitu biaya jasa outsourcing cleaning service dan catering yaitu biaya jasa outsourcing catering. 


\section{Metode Analisis}

Penelitian ini menggunakan analisis biaya yang relevan dan strategis dalam pengambilan keputusan untuk membuat (dalam hal ini mempekerjakan sendiri), menyewa, atau membeli. Menurut Blocher dkk (2008): "Relevant cost are cost that will be incurred at some future time; they differ for each option available to the decision maker." Atau dapat diartikan biaya yang dikeluarkan pada masa yang akan datang; berbeda untuk setiap pilihan yang tersedia bagi pengambil keputusan. Dapat disimpulkan biaya relevan adalah biaya yang berbeda atas setiap alternatif keputusan pada masa yang akan datang.

Perusahaan yang saat ini mempekerjakan sendiri kegiatan penunjangnya yaitu bidang cleaning service dan juga memberikan uang makan bagi karyawan memiliki alternatif menggunakan outsourcing. Dari alternatif tersebut perlu dilakukan analisis biaya apa saja yang relevan untuk dapat diambil keputusan dilihat dari alternatif yang menghasilkan biaya paling rendah. Data yang akan diolah adalah biaya-biaya relevan apa saja yang dikeluarkan perusahaan untuk setiap alternatif yang ada yaitu: mempekerjakan sendiri (karyawan cleaning service dan pemberian uang makan siang atau menggunakan outsourcing (cleaning service dan catering).

Setelah mengetahui berapa besar biaya relevan yang dikeluarkan perusahaan untuk mempekerjakan sendiri kegiatan penunjangnya maka akan dibandingkan dengan biaya yang dikeluarkan perusahaan apabila menggunakan outsourcing. Kondisi dan keadaan yang tidak stabil di Indonesia tentu akan mengakibatkan sulitnya memprediksi kenaikan biaya yang terjadi pada masa yang akan datang. Oleh karena itu perlu dibuat tiga skenario untuk memperkirakan kenaikan biaya outsourcing yang terjadi tahun berikutnya yang akan berbeda untuk setiap alternatif penggunaan outsourcing, yaitu: pesimis dengan asumsi kenaikan biaya outsourcing 10\%; moderat dengan asumsi kenaikam biaya outsourcing $7.5 \%$; dan optimis dengan asumsi kenaikan biaya outsourcing $5 \%$.

Setelah mengetahui biaya dan efisiensi yang diperoleh perusahaan jika memilih alternatif menggunakan outsourcing cleaning service dibandingkan dengan alternatif mempekerjakan sendiri karyawan cleaning service, selanjutnya menghitung biaya dan efisiensi yang diterima perusahaan jika menggunakan outsourcing bidang catering dibandingkan dengan perusahaan memilih alternatif memberikan uang makan kepada karyawannya dengan tiga skenario yang ada.

\section{HASIL DAN PEMBAHASAN}

\section{Analisis Biaya Relevan}

Untuk menganalisis biaya relevan yaitu menentukan biaya-biaya apa saja yang relevan terhadap keputusan yang akan diambil perusahaan. Kemudian menghitung selisih dari biaya yang relevan antara dua alternatif keputusan. Keputusan yang diambil yaitu melihat hasil yang lebih efisien bagi perusahaan. Perhitungan dilakukan dengan asumsi kegiatan perusahaan dalam satu tahun terakhir selama tahun 2010 apabila perusahaan memilih mempekerjakan sendiri dalam hal ini karyawan cleaning service dan juga pemberian uang makan siang dan apabila perusahaan memilih menggunakan outsourcing cleaning service dan juga catering.

\section{Analisis Biaya Mempekerjakan Sendiri (Self Hiring)}

Tabel 1 menunjukkan data biaya relevan yang dikeluarkan perusahaan untuk mempekerjakan sendiri kegiatan penunjangnya. 
Tabel 1 Biaya Mempekerjakan Sendiri Bidang Cleaning Service

\begin{tabular}{lrc}
\hline Bidang Cleaning Service (Self Hiring) $\mathbf{2 0 1 0}$ & Biaya (Rp) & Biaya dalam Satu Tahun (Rp) \\
\hline Gaji per bulan & $1,200,000$ & $14,400,000$ \\
Transport Karyawan : (Rp10.000 x 30hari) & 300,000 & $3,600,000$ \\
Seragam Kerja Karyawan & 150,000 & 150,000 \\
Peralatan Kebersihan & 200,000 & 200,000 \\
Uang Makan Karyawan : (Rp15.000 x 30hari) & 450,000 & $5,400,000$ \\
Biaya Pelatihan Karyawan & 100,000 & 100,000 \\
Biaya recruitment Karyawan & 250,000 & 250,000 \\
Asuransi Untuk karyawan & 50,000 & 600,000 \\
\hline \multicolumn{2}{c}{ Total Biaya Relevan : }
\end{tabular}

Sumber: Data diolah

\section{Biaya Makan (Catering) Karyawan}

Perusahaan selama ini memberikan uang makan siang bagi karyawan sehingga karyawan sendiri yang membeli makan siangnya ketika waktu istirahat. Tabel 2 merupakan data biaya relevan yang dikeluarkan perusahaan untuk memberikan makan siang.

Tabel 2 Biaya Makan Karyawan

\begin{tabular}{ccc}
\hline Biaya Makan Karyawan $\mathbf{2 0 1 0}$ & $\begin{array}{c}\text { Biaya per Bulan } \\
\text { (Rp) }\end{array}$ & $\begin{array}{c}\text { Biaya Dalam Satu } \\
\text { Tahun (Rp) }\end{array}$ \\
\hline Biaya Makan Karyawan per bulan: (Rp450.000 x 11 orang) & $4,950,000$ & $59,400,000$ \\
\hline Total Biaya Relevan : & & $\mathbf{5 9 , 4 0 0 , 0 0 0}$ \\
\hline \multicolumn{2}{c}{ Sumber: Data diolah }
\end{tabular}

Perusahaan mengeluarkan biaya makan bagi karyawan sebesar Rp59.400.000,00 setiap tahunnya. Karyawan diberikan uang makan sebesar Rp15.000,00 per orang setiap harinya (Rp450.000,00 per bulan) dan juga waktu istirahat untuk makan siang. Situasi tersebut membuat karyawan harus keluar untuk membeli sendiri makan siang dan tentunya menyebabkan berbagai hal. Dampak negatif pertama adalah waktu makan siang karyawan menjadi tidak teratur karena karyawan harus keluar sendiri untuk membeli makan siangnya. Sementara dampak negatif kedua adalah mengganggu proses kerja perusahaan jika karyawan terlambat kembali ke kantor setelah istirahat makan. Sementara itu, dampak positif pertama karyawan dapat bebas memilih menu makan siang sesuai kebutuhan masing-masing. Kedua, karyawan dapat keluar dari kantor untuk beristirahat. Ketiga, karyawan dapat menentukan sendiri uang makan yang diberikan untuk makan siang atau disimpan untuk menambah penghasilan.

\section{Analisis Biaya Penggunaan Outsourcing}

Berikut adalah data biaya relevan yang dikeluarkan perusahaan apabila menggunakan outsourcing dalam kegiatan penunjangnya.

\section{Biaya Outsourcing Jasa Cleaning Service}

Tabel 3 menunjukkan asumsi biaya relevan yang akan dikeluarkan perusahaan apabila perusahaan memilih menggunakan outsourcing jasa cleaning service. Dalam hal ini perusahaan harus dengan teliti mempertimbangkan setiap biaya yang mungkin akan diperhitungkan. Periode kontrak 
sebaiknya ditentukan dari awal apakah secara mingguan, bulanan, atau tahunan. Hal ini akan berpengaruh terhadap perhitungan biaya jika mempekerjakan sendiri.

Tabel 3 Biaya Outsourcing Jasa Cleaning service

\begin{tabular}{|c|c|}
\hline Outsourcing Jasa Cleaning service 2010 & Biaya Dalam Satu Tahun (Rp) \\
\hline Paket Jasa dalam setahun : (Rp1.500.000 x 12 Bulan) & $18,000,000$ \\
\hline Total & $18,000,000$ \\
\hline
\end{tabular}

\section{Biaya Outsourcing Jasa Catering}

Tabel 4 merupakan asumsi biaya relevan yang akan dikeluarkan perusahaan apabila menggunakan outsourcing catering untuk memberikan makan siang bagi karyawan. Dalam hal ini perusahaan harus memperhitungkan setiap biaya yang mungkin akan dikeluarkan. Periode kontrak perusahaan sebaiknya ditentukan dari awal apakah secara harian, mingguan, atau bulanan. Hal ini akan berpengaruh terhadap perhitungan biaya apakah memberikan uang makan atau menggunakan outsourcing jasa catering.

Tabel 4 Biaya Outsourcing Jasa Catering

\begin{tabular}{ccc}
\hline Outsourcing Jasa Catering $\mathbf{2 0 1 0}$ & Biaya (Rp) & Biaya Dalam satu Tahun (Rp) \\
\hline Jasa Paket per bulan Rp360.000 x 11 orang & $3,960,000$ & $47,520,000$ \\
\hline Total: & $\mathbf{4 7 , 5 2 0 , 0 0 0}$ \\
\hline \multicolumn{2}{c}{ Sumber: Data diolah }
\end{tabular}

Total biaya yang dikeluarkan perusahaan apabila menggunakan outsourcing catering adalah sebesar Rp47.520.000,00 setiap tahunnya. Perusahaan catering tentunya memberikan menu makan siang dengan berbagi jenis pilihan menu yang bervariasi setiap harinya dan juga memenuhi standar gizi yang terdiri dari nasi, ikan, sayur, dan buah. Menu makan yang diberikan juga terjaga kebersihannya sehingga karyawan tidak perlu takut untuk mengonsumsi makanan catering. Ketepatan dalam pengiriman dan pengambilan paket catering, sehingga tidak perlu terjadi keterlambatan bagi karyawan untuk makan siang. Tentunya, hal ini dapat mengurangi gangguan dalam pelaksanaan dan kinerja dari karyawan perusahaan.

Berdasarkan tabel 4, penghematan yang cukup signifikan bagi perusahaan dibandingkan dengan memberikan biaya uang makan bagi karyawan yang jumlahnya mencapai Rp.59.400.000,00. Perusahaan juga mendapat keuntungan dengan menggunakan outsourcing catering sebagai berikut. Pertama, dengan disediakannya catering maka karyawan dapat langsung makan siang di kantor tanpa harus meninggalkan kantor. Kedua, tentunya dapat mengurangi keterlambatan masuk setelah istiarahat makan siang karena karyawan tetap berada di kantor. Ketiga, karyawan tidak perlu menghabiskan waktu untuk membeli makan siang di luar kantor.

\section{Analisis Efisiensi Biaya}

Analisis efisiensi biaya dilakukan dengan menghitung biaya relevan dari masing-masing alternatif yang ada untuk mengambil keputusan. Perusahaan memiliki dua alternatif yaitu 
mempekerjakan sendiri karyawan bidang cleaning service dan memberikan uang makan siang atau perusahaan menggunakan outsourcing baik cleaning service untuk mengurus kebersihan dan juga outsourcing catering untuk penyediaan makan siang karyawan. Keputusan yang diambil adalah berdasarkan alternatif mana yang lebih menghasilkan biaya yang paling rendah. Tabel 5 menunjukkan data yang disediakan perusahaan apabila mempekerjakan sendiri atau menggunakan outsourcing.

Tabel 5 Efisiensi Biaya

\begin{tabular}{cccc} 
& $\begin{array}{c}\text { Keputusan } \\
\text { Mempekerjakan sendiri } \\
(\mathbf{R p})\end{array}$ & $\begin{array}{c}\text { Keputusan Menggunakan } \\
\text { Outsourcing (Rp) }\end{array}$ & Efisiensi (Rp) \\
\hline Cleaning Service & $24,700,000$ & $18,000,000$ & $6,700,000$ \\
Biaya Makan/Catering & $59,400,000$ & $47,520,000$ & $11,880,000$ \\
\hline Total : & $\mathbf{8 4 , 1 0 0 , 0 0 0}$ & $\mathbf{6 5 , 5 2 0 , 0 0 0}$ & $\mathbf{1 8 , 5 8 0 , 0 0 0}$ \\
\hline
\end{tabular}

Sumber: Data diolah

Dengan demikian maka sebaiknya keputusan yang diambil oleh perusahaan adalah menggunakan outsourcing catering dengan penghematan setiap tahunnya Rp11.880.000,00 dan outsourcing cleaning service dengan penghematan dan efisiensi biaya Rp6.700.000,00. Total efisiensi seluruh kegiatan penunjangnya apabila menggunakan outsourcing adalah sebesar Rp18.580.000,00 yang didapat dari (a) Rp.11.880.000,00 + Rp.6.700.000,00 apabila melihat dari sisi efisiensi; dan (b) Rp84.100.000,00 - Rp65.520.000,00 apabila melihat dari total biaya setiap alternatif mempekerjakan sendiri dan menggunakan outsourcing.

\section{Analisis Sensitivitas}

Analisis sensitivitas ini dilakukan karena ada kemungkinan kenaikan biaya pada tahun berikutnya dengan berbagai asumsi kenaikan harga. Pada 2011 kenaikan UMR (Upah Minimum Regional) DKI Jakarta menjadi Rp.1.290.000 (Charysa, 2013) sehingga perusahaan akan menyesuaikan gaji karyawan sesuai dengan UMR yang ditetapkan pemerintah daerah. Dengan kenaikan UMR menjadi Rp.1.290.000,00, maka perusahaan harus menaikan gaji karyawan cleaning service sebanyak 7.5\% dari Rp1.200.000,00. Hal ini akan mengakibatkan kenaikan biaya relevan pada tahun berikutnya.

\section{Asumsi Analisis Mempekerjakan Sendiri (self hiring) Tahun 2011}

Berikut asumsi biaya relevan yang dikeluarkan perusahaan untuk mempekerjakan sendiri karyawan cleaning service pada 2011. Ada asumsi bahwa terjadi kenaikan kebutuhan bahan pokok pada 2011. Tentunya hal ini akan mengakibatkan tuntutan kenaikan berbagai jenis biaya yang di keluarkan perusahaan bagi karyawannya. Kenaikan yang terjadi tentunya akan berpengaruh terhadap perhitungan biaya yang akan dikeluarkan perusahaan untuk ke depannya.

\section{Asumsi Biaya Mempekerjakan Sendiri Bidang Cleaning Service Tahun 2011}

Asumsi biaya mempekerjakan sendiri kegiatan cleaning service pada 2011 yang akan dikeluarkan perusahaan selama satu tahun ditunjukkan dalam Tabel 6. Asumsi kenaikan adalah mengikuti kenaikan UMR tahun 2011 yaitu sebesar 7.5\% dan biaya relevan lainnya dengan asumsi kenaikan tahunan yang terjadi di Indonesia. Asumsi kenaikan biaya lainnya akan mengikuti kenaikan tahunan yang biasa terjadi di Indonesia. 
Tabel 6 Asumsi Biaya Memperkerjakan Sendiri Bidang Cleaning Service Tahun 2011

\begin{tabular}{lcc}
\hline \multicolumn{3}{c}{ Asumsi Kenaikan Gaji 7.5\% } \\
\hline Bidang Cleaning service (Self Hiring) $\mathbf{2 0 1 1}$ & Biaya (Rp) & Biaya Dalam Satu Tahun (Rp) \\
\hline Gaji per bulan Naik 7.5\% & $1,290,000$ & $15,480,000$ \\
Transport : (Rp15.000 x 30hari) & 450,000 & $5,400,000$ \\
Seragam Kerja & 200,000 & 200,000 \\
Peralatan Kebersihan & 220,000 & 220,000 \\
Biaya makan: (Rp17.000 x 30hari) & 510,000 & $6,120,000$ \\
Biaya Pelatihan & 100,000 & 100,000 \\
Asuransi & 55,000 & 660,000 \\
\hline \multicolumn{1}{c}{ Total Biaya Relevan } & $\mathbf{2 8 , 1 8 0 , 0 0 0}$ \\
\hline
\end{tabular}

Sumber: Data diolah

\section{Asumsi Biaya Makan Karyawan Tahun 2011}

Berikut adalah asumsi biaya makan karyawan yang akan dikeluarkan perusahaan pada tahun 2011 selama satu tahun. Asumsi perusahaan akan memberikan kenaikan biaya uang makan karyawan yang semula Rp15.000,00 per orang dalam sehari menjadi Rp17.000,00 per orang dalam sehari.

Kenaikan Biaya makan karyawan menjadi Rp510.000 atau Rp17.000 per orang (naik Rp2.000,00 yang pada tahun sebelumnya adalah sebesar Rp15.000,00) dalam sehari disesuaikan dengan kenaikan kebutuhan bahan pokok dan kenaikan biaya atau upah makan yang biasa terjadi setiap tahun di perusahaan. Hal ini menyebapkan perusahaan akan mengeluarkan total biaya untuk uang makan karyawan menjadi Rp73.440.000,00 dibandingkan tahun lalu yang sebesar Rp59.400.000,00 dalam setahun.

\section{Asumsi Analisis Biaya Penggunaan Outsourcing Tahun 2011}

Asumsi biaya relevan tahun 2011 apabila perusahaan menggunakan outsourcing dalam kegiatan penunjang. Terdapat tiga skenario yang menjadi asumsi kenaikan biaya outsourcing yaitu: pesimis, dengan asumsi kenaikan biaya outsourcing per tahun adalah 10\%; moderat dengan asumsi kenaikan biaya outsourcing per tahun adalah 7.5\%; optimis dengan asumsi kenaikan biaya outsourcing per tahun adalah 5\%. Tabel 7 menunjukkan perbandingan biaya keputusan mempekerjakan sendiri dengan keputusan outsourcing berdasarkan 3 skenario.

Tabel 7 Perbandingan Biaya Keputusan Mempekerjakan Sendiri dengan Keputusan Outsourcing Berdasarkan 3 Skenario

\begin{tabular}{|c|c|c|c|c|}
\hline & $\begin{array}{c}\text { Keputusan } \\
\text { Mempekerjakan } \\
\text { Sendiri }\end{array}$ & $\begin{array}{l}\text { Keputusan } \\
\text { Menggunakan } \\
\text { Outsourcing }\end{array}$ & Skenario Kenaikan & $\begin{array}{l}\text { Efisiensi } \\
\text { Biaya }\end{array}$ \\
\hline Cleaning Service & Rp28,180,000 & $\begin{array}{l}\text { Rp18,900,000 } \\
\text { Rp19,350,000 } \\
\text { Rp19,800,000 } \\
\end{array}$ & $\begin{array}{l}\text { Optimis: Kenaikan 5\% } \\
\text { Moderat: Kenaikan 7.5\% } \\
\text { Pesimis: Kenaikan 10\% }\end{array}$ & $\begin{array}{l}\text { Rp9,280,000 } \\
\text { Rp8,830,000 } \\
\text { Rp8,380,000 }\end{array}$ \\
\hline $\begin{array}{c}\text { Memberikan Uang } \\
\text { Makan/Catering }\end{array}$ & Rp73,440,000 & $\begin{array}{l}\text { Rp49,896,000 } \\
\text { Rp51,084,000 } \\
\text { Rp52,272,000 }\end{array}$ & $\begin{array}{c}\text { Optimis: Kenaikan 5\% } \\
\text { Moderat: Kenaikan 7.5\% } \\
\text { Pesimis: Kenaikan 10\% }\end{array}$ & $\begin{array}{l}\text { Rp23,544,000 } \\
\text { Rp22,356,000 } \\
\text { Rp21,168,000 }\end{array}$ \\
\hline
\end{tabular}

Sumber: Data Diolah 


\section{SIMPULAN}

Berdasarkan hasil pembahasan, dapat disimpulkan sebagai berikut. Pertama, efisiensi biaya yang didapat oleh PT Kuwera Jaya atas keputusan alternatif mempekerjakan sendiri dan menggunakan outsourcing pada bidang cleaning service adalah sebesar Rp6.700.000,00 yaitu dari selisih biaya mempekerjakan sendiri sebesar Rp24.700.000,00 dikurangi biaya menggunakan outsourcing sebesar Rp18.000.000,00. Kedua, efisiensi biaya yang didapat oleh PT Kuwera Jaya atas keputusan alternatif mempekerjakan sendiri dan menggunakan outsourcing pada bidang catering adalah sebesar Rp11.880.000,00 yaitu dari selisih biaya mempekerjakan sendiri sebesar Rp59.400.000,00 dikurangi biaya menggunakan outsourcing sebesar Rp47.520.000,00. Ketiga, PT Kuwera Jaya layak memilih alternatif menggunakan outsourcing dalam kegiatan penunjangnya walaupun dengan adanya tiga skenario asumsi kenaikan harga yaitu skenario pesimis, moderat, dan optimis.

\section{Saran}

Berdasarkan simpulan yang ada, beberapa saran dapat diberikan. Sebaiknya PT Kuwera Jaya segera menggunakan outsourcing dalam kegiatan penunjang baik di bidang cleaning service maupun catering karena akan jauh lebih menghemat uang perusahaan dibandingkan dengan mempekerjakan sendiri. PT Kuwera Jaya juga harus selalu memeriksa, mengawasi, menganalisis, dan mengetahui keadaan yang terjadi apabila sudah menggunakan outsourcing nantinya. Selain itu, PT Kuwera Jaya juga memonitor kinerja karyawan outsourcing untuk memastikan bahwa standar kerja sesuai dengan kontrak kerja. Terakhir, PT Kuwera Jaya memerhatikan kesejahteraan karyawan, baik karyawan tetap maupun karyawan outsourcing.

\section{DAFTAR PUSTAKA}

Alma, B. (2003). Kewirausahaan. Bandung: Alfabeta.

Blocher, E. J., Chen, K. H., Cokins, G. \& Lin, T. W. (2007). Manajemen Biaya. Edisi ke-3 Buku 2. Jakarta: Salemba Empat.

Charysa, N. N. (2013). Pengaruh pertumbuhan ekonomi dan inflasi terhadap upah minimum regional di kabupaten/kota provinsi Jawa Tengah tahun 2008-2011. Economics Development Analysis Journal, $\quad 2(4), \quad 277-285 . \quad$ Available http://journal.unnes.ac.id/sju/index.php/edaj/article/view/2489/2283

David, F. R. (2011). Strategic Management Concepts And Cases. 13th Ed. New Jersey: Pearson Education.

Faiz, P. M. (2007, 20 Mei). Outsourcing (Alih Daya) dan Pengelolaan Tenaga Kerja pada Perusahaan: Tinjauan Yuridis Terhadap Undang-Undang Nomor 13 Tahun 2003 Tentang Ketenagakerjaan. Diakses dari http://jurnalhukum.blogspot.com/2007/05/outsourcing-dantenaga-kerja.html

Horngren, C. T., Datar, S. M., \& Foster, G. (2008). Akuntansi Biaya. Jilid I. Jakarta: Erlangga.

Madura, J. (2007). Pengantar Bisnis. Jakarta: Salemba Empat.

Quinn, J. B. \& Hilmer, F. G. (1994). Strategic outsourcing. Sloan Management Review, 35(4), 43-55. 
Sugiono. (2004). Metode Penelitian Bisnis. Edisi ke-6. Bandung: Alfabeta.

Suryana. (2008). Kewirausahaan Pedoman Praktis, Kiat, dan Proses Menuju Sukses. Edisi ke-3. Jakarta: Salemba Empat.

Usry, Carter, \& Thomson. (2004). Akutansi Biaya. Edisi ke-13. Jakarta: Salemba Empat.

Wirawan. (n.d.). Apa yang dimaksud dengan sistem outsourcing? Rubrik Hukum Teropong. http://www.pikiran-rakyat.com/cetak/0504/31/teropong/komenhukum.htm 